\title{
Pengaruh Harga Dan Biaya Promosi Terhadap Peningkatan penjualan Tiket pada PT. Pakem Tours dan Travel Makassar
}

\section{The Effect of Price and Promotion Costs on the Increase in Ticket sales at PT. Pakem Tours and Travel Makassar}

\author{
Ady Kurnia ${ }^{1}$, Renny Mointi ${ }^{2}$ Ridwan $^{3}$ \\ ${ }^{1,2}$ Manajemen, Universitas Indonesia Timur \\ (akurady99@gmail.com \\ (rennymointi@gmail.com ) \\ ${ }^{3}$ Magister manajemen, Pasca sarjana ,STIM LPI Makassae
}

\begin{abstract}
ABSTRAK
Penelitian bertujuan mengetahui pengaruh harga terhadap peningkatan volume penjualan tiket serta untuk mengetahui biaya promosi terhadap PT. Pakem Tours dan Travel Makassar. Penelitian ini menggunakan metode deskriptif dengan pendekatan kualitatif, metode analisis yang digunakan yaitu deskriptif.. Dari hasil penelitian diperoleh persamaan $Y=308.426+0,639 X_{1}+0,405 X_{2}$, di mana b0 $=304,426$ merupakan nilai konstanta. Hasil analisis korelasi menunjukkan bahwa antara harga dan biaya promosi, terdapat hubungan yang signifikan dalam peningkatan volume penjualan sebab $\mathrm{R}=$ 0,957 , sedangkan $R^{2}=0,915$ yang artinya secara bersamaan antara harga dan promosi mempengaruhi meningkatnya penjualan tiket. Dari hasil penelitian ini dapat dilihat dari metode deskriptif yakni penjualan tiket tiap tahunnya mengalami peningkatan yang sangat baik dimana harga dan promosi sangat berperan penting terhadap peningkatan penjualan tiket pada PT. Pakem Tours dan Travel Makassar
\end{abstract}

Kata Kunci: Biaya promosi, harga, peningkatan penjualan

ABSTRAK

This study aims to determine the effect of price on increasing the volume of ticket sales and to determine the cost of promotion to PT. Pakem Tours and Travel Makassar. This study uses a descriptive method with a qualitative approach, the analysis method used is descriptive. From the results of the study, the equation $Y=308.426+0.639 X \_1+0.405 X \_2$ is obtained, where b0= 304.426 is a constant value. The results of the correlation analysis show that between price and promotion costs, there is a significant relationship in the increase in sales volume because $R=0.957$, while $R \wedge 2=0.915$, which means that simultaneously between price and promotion affects the increase in ticket sales. From the results of this study, it can be seen from the descriptive method, namely that ticket sales each year have increased very well where prices and promotions play an important role in increasing ticket sales at PT. Pakem Tours and Travel Makassar

Keywords: Promotion costs, price, sales increase

\section{PENDAHULUAN}

Setiap tahunnya persaingan usaha semakin meningkatkan dengan sangat tajam, apalagi jika berhubungan dengan unit usaha perusahaan. Semakin hari terdapat perusahaan baru yang menawarkan produk dengan berbagai jenis yang berkualitas dengan harga yang sangat bersaing, tawaran mereka sangat menjadi ancaman bagi perusahaan yang berdiri lebih awal, begitupun dengan perusahaan yang bergerak dibidang travel khususnya penjualannya tiket. Untuk menghadapi persaingan yang semakin hari kian ketat adalah dengan penetapan strategi harga dan promosi.

Harga menjadi salah satu unsur dari bauran pemasaran yang menjadi strategis untuk meningkatkan volume penjualan. Selain harga, promosi juga menjadi variabel yang mempengaruhi tingkat volume penjualan 
Promosi dapat dipilih perusahaan untuk memberikan informasi, menyampaikan, bujukan, dan pengaruhi konsumen dalam memutuskan pembelian produk oleh konsumen yang ditawarkan perusahaan.

Pentingnya promosi dan harga maka menjadi sangat perlu menjadi perhatian bagi setiap perusahaan PT Pakem Tours dan Travel Makassar, yang menawarkan tiket kepada konsumen. Upaya ini dilakukan guna menghadapi persaingan yang kian sulit dengan perusahaan sejenis lainnya.

Subagyo ( $2010: 311$ ) mengemukakan bahwa, tujuan pemasaran adalah apa yang ingin kita capai, sebuah tujuan pemasaran memperhatikan keseimbangan antara produk dan target pasar. Ini berhubungan dengan produk apa yang kita jual pada pasar tertentu supaya meningkatkan volume penjualan, memberikan kepuasan kepada pelanggan, dan memaksimalkan laba.

Menurut Hardjanto ( 2005:145 ), harga merupakan penentuan dari suatu produk yang merupakan titik pertemuan dari produk yang ditawarkan dengan permintaan akan produk yang dimaksud. Metode penetapan harga merupakan suatu keputusan yang penting di dalam pemasaran dari suatu produk.

Harga menjadin bagian elemen bauran pemasaran yang sangat fleksibel. Harga harga akan lebih mudah dirubah, berbeda dengan ciri khas produk dan perjanjian distribusi. Namun menjadi permasalahan baru penetapan harga sangat mempengaruhi permasalahan yang akan dihadapi perusahaan.

Promosi menjadi wadah berkomunikasi yang persuasif, mengajak, mendesak, membujuk, mempengaruhi serta membuat yakin. Ciri dari komunikasi yang persuasif membujuk adalah adanya komunikator yang secara terencana mengatur berita/informasi dan cara penyampaiannya.
Suatu produk meskipun sangat bermanfaat namun jika tidak diperkenalkan kepada konsumen, produk akan menjadi tidak dapat dimengerti manfaat serta kegunaanya. Ini menjadi penting bagi perusahaan untuk mempengaruhi dan menjadikan konsumen memutuskan membeli atas peroduk yang ditawarkan.

Subagyo ( $2010: 129$ ) mengemukakan bahwa promosi adalah semua kegiatan yang dimaksudkan untuk menyampaikan atau mengkomunikasikan suatu produk kepada pasar sasaran, untuk memberi informasi tentang keistimewaan, kegunaan dan yang paling penting adalah tentang keberadaannya, untuk mengubah sikap ataupun untuk mendorong orang untuk bertindak dalam membeli suatu produk.

Menurut Sutojo ( 2009 : 265 ) promosi adalah kegiatan yang dilakukan untuk memberitahu pembeli tentang keberadaan produk di pasar atau kebijaksanaan permasaran tertentu yang baru ditetapkan perusahaan misalnya pemberian bonus pembelian atau pemotongan harga.

Menurut Subagyo (2010 : 133), tujuan utama dari promosi yang akan dilakukan oleh perusahaan secara mendasar terdiri dari beberapa alternatif, antara lain : menginformasikan, mempengaruhi, membujuk dan mengingatkan sasaran konsumen tentang perusahaan dan bauran pemasarannya. Secara singkat dapat dikatakan bahwa tujuan promosi yang dilakukan berkaitan erat dengan upaya bagaimana konsumen atau calon konsumen dapat mengenal produk perusahaan, lalu memahaminya, berubah sikap, menyukai, yakin dan pada akhirnya membeli dan selalu ingat akan produk tersebut.

Tjiptono ( 2009 : 222 ) mengemukakan bahwa bentuk - bentuk promosi menurut tugas khusus yaitu, personal selling, mass selling, terdiri atas periklanan dan publisitas. Promosi penjualan. public 
relations (hubungan masyarakat), dan direct marketing.

Penjualan merupakan tujuan utama dilakukannya kegiatan perusahaan. Perusahaan dalam menghasilkan barang / jasa, memunyai tujuan akhir yaitu menjual barang / jasa tersebut kepada masyarakat. Penjualan yang dilakukan oleh perusahaan bertujuan untuk menjual barang/jasa yang diperlukan sebagai sumber pendapatan untuk menutup semua ongkos guna memperoleh laba.

Usaha penjualan menjadi kegiatan pelengkap atau suplemen dari pembelian, yang mengakibatkan terjadinya transaksi. Jadi kegiatan pembelian dan penjualan menjadi satu kesatuan untuk dapat terjadi pertukaran uang dan barang atau jasa seperti halnya kegiatan pembelian, terdiri dari serangkaian kegiatan yang meliputi penciptaan permintaan (demand), menemukan si pembeli, negosiasi, harga, dan syarat - syarat pembayaran.

Kegiatan pejualan yang dilaksanakan oleh perusahaan bertujuan untuk mencapai volume penjualan yang diharapkan dan menguntungkan untuk mencapai laba maksimum bagi perusahaan. Pengertian penjualan menurut Marbun ( 2003 : 225 ) adalah "total barang yang terjual oleh perusahaan dalam jangka waktu tertentu".

Menurut Rangkuti ( 2009 : 207 ) bahwa volume penjualan adalah pencapaian yang dinyatakan secara kuantitatif dari segi fisik atau volume atau unit suatu produk. Volume penjualan merupakan suatu yang menandakan naik turunnya penjualan dan dapat dinyatakan dalam bentuk unit, kilo, ton atau liter. Volume penjualan merupakan jumlah total yang dihasilkan dari kegiatan penjualan barang. Semakin besar jumlah penjualan yang dihasilkan perusahaan, semakin besar kemungkinan laba yang akan dihasilkan perusahaan.

Terdapat beberapa indikator dari volume penjualan yang dikutip dari Kotler oleh Swastha ( 2008 : 404 ) yaitu : (a) mencapai volume penjualan, mendapatkan laba, dan (c) menunjang pertumbuhan perusahaan.

Dari definisi di atas dapat disimpulkan bahwa jumlah volume penjualan adalah keseluruhan penjualan yang dinilai dengan unit oleh perusahaan dalam kurun waktu tertentu dalam memperoleh keuntungan yang besarl yang dapat mendukung pertumbuhan perusahaan.

Berdasarkan uraian dari teori - teori yang telah dipaparkan penelitian ini bertujuan untuk: (1) untuk mengetahui pengaruh harga terhadap peningkatan volume penjualan tiket pada PT Pakem Tours dan Travel Makassar, dan (2) untuk mengetahui pengaruh biaya promosi terhadap peningkatan volume penjualan tiket pada PT Pakem Tours dan Travel Makassar.

\section{METODE PENELITIAN}

Penelitian ini menggunakan metode deskriptif dengan pendekatan kualitatif. Penelitian ini pada PT Pakem Tours dan Travel Makassar, dan waktu penelitian ini yaitu pada bulan Agustus. Populasi penelitian ini adalah karyawan karyawan PT Pakem Tours dan Travel Makassar yang berkaitan dengan peningkatan penjualan tiket yaitu sebanyak 11 orang. Penarikan sampel bersifat sampel jenuh.

Metode pengumpulan data yang dilakukan adalah dengan metode observasi, wawancara, dan dokumentasi. Metode analisis yang digunakan dalam penelitian ini adalah analisis deskriptif dan metode analisis regresi linier berganda menurut Akdom ( $2007: 142$ ) yaitu $\mathrm{Y}=$ $b_{0}+b_{1} X_{1}+b_{2} X_{2}+$ e, di mana:

$\mathrm{Y}=$ Penjualan tiket (unit)

$X_{1}=$ Harga jual ( Rupiah )

$X_{2}=$ Biaya Promosi ( Rupiah )

$b_{0}=$ Nilai konstanta

$b_{1}, b_{2}=$ Koefisien regresi

$\mathrm{e}=$ Standar Error 


\section{HASIL DAN PEMBAHASAN}

Industri pariwisata di Sulawesi Selatan menjadi industri yang mengalami pertumbuhan sangat pesat, dalam kurun waktu beberapa tahun terakhir. Di ibukota provinsi yaitu makassar travel - travel bermunculan dengan beragam macam penawaran menjadi tidak terbendung, kemudahan perjalanan ketempat pariwisata serta paket - paket promosi yang sangat menarik dan harga yang sangat terjangkau. Selain itu travel agen tersebut memberikan pelayanan tour domestik dan internasional.

PT Pakem Tours \& Travel Indonesia berdiri sejak tahun 2002. Dalam perkembangannya perusahaan kepuasan konsumen menjadi prioritas utamanya untuk memberikan pelayanan yang berkesan untuk mempertahankan konsumen dalam menggunakan pelayanan perusahaan dimusim musim berikutnya. perushaan ini telah banyak memilki sub agent di beberapa kota selain Kota Makassar.

Prinsip perusahaan adalah bahwa organisasi yang baik akan menjadi faktor dalam mencapai tujuan perusahaan

Organisasi dalam suatu perusahaan merupakan sarana yang sangat penting dalam menetapkan langkah dimana suatu kegiatan akan dilaksanakan dan siapa yang akan melaksanakannya, jadi ada pembagian tugas wewenang dan tanggung jawab yang dapat disimpulkan secara garis besarnya dalam suatu bagan atau skema tergantung dari perusahaan yang bersangkutan.

\section{Perkembangan Penjualan Tiket}

Untuk meningkatkan tingkat volume penjualan, salah satu upaya yang ingin dicapai oleh setiap unit usaha jasa travel adalah dengan meningkatkan hasil penjualan tiket, sehingga mampu menopang kinerja dan produktivitas perusahaan

Dalam upaya peningkatan volume penjualan tiket, hal yang perlu diperhatikan berpengaruh adalah dengan melakukan perbaikan produktivitas penjualan menyalurkan tiket. Sebab dengan memperhatikan faktor penentu pemasaran, mengakibatakan memengaruhi volume penjualan.

Pelaksanaan kegiatan penjualan tiket perusahaan sejak tahun 2011 sampai dengan 2014 terjadi pertumbuhan penjualan yang sangat massif. Dengan adanya peningkatan penjualan yang cukup signifikan pada tahun 2012 maka upaya menganalisis penjualan dalam pemasaran tiket. Bertujuan untuk memperoleh informasi mengenai kenaikan serta turunanya volume penjualan tiket pada kurun waktu 4 tahun terakhir ( tahun 2011 -2014 ).

Tabel berikut menyajikan menganalisis volume tingkat penjualan tiket dalam kurun waktu 4 tahun terakhir, terlihat pada tabel 1 di bawah :

Tabel. 1. Perkembangan volume penjualan tiket tahun 2011 - 2014

\begin{tabular}{cccc}
\hline Tahun & $\begin{array}{c}\text { Volume Penjualan } \\
\text { (lembar) }\end{array}$ & Harga Jual (Rp) & Nilai Penjualan (Rp) \\
\hline $\mathbf{2 0 1 1}$ & 1.022 & Rp. 764.000 & Rp. 780.808.000 \\
\hline $\mathbf{2 0 1 2}$ & 1.118 & Rp. 809.000 & Rp. 904.462.000 \\
\hline $\mathbf{2 0 1 3}$ & 1.131 & Rp. 846.000 956.826 .000 \\
\hline $\mathbf{2 0 1 4}$ & 1.135 & Rp. 869.000 & Rp. 986.315.000 \\
\hline Rata - Rata & 1.102 & Rp. 822.000 & Rp. 907.102.750 \\
\hline
\end{tabular}

Sumber : PT Pakem Tours \& Travel Makassar 
Berdasarkan data volume penjualan tiket pada PT Pakem Tours \& Travel, maka dapat disajikan laju pertumbuhan penjualan tiket tahun 2011/2012 sebesar 9.4\%, tahun 2012/2013 sebesar $1.18 \%$, dan tahun 2013/2014 sebesar $1.135 \%$. Untuk lebih jelasnya hasil perhitungan pertumbuhan penjualan tiket yang dapat dilihat pada tabel 2 di bawah ini.

Tabel 2. Perkembangan volume penjualan tiket

\begin{tabular}{cccc}
\hline Tahun & $\begin{array}{c}\text { Volume Penjualan Tiket } \\
\text { ( lembar })\end{array}$ & \multicolumn{2}{c}{ Perkembangan Penjualan } \\
\cline { 3 - 4 } & 1.022 & Lembar & $\%$ \\
\hline $\mathbf{2 0 1 1}$ & 1.118 & - & - \\
$\mathbf{2 0 1 2}$ & 1.131 & 16 & 1,4 \\
$\mathbf{2 0 1 4}$ & 1.135 & 4 & 3,53 \\
\hline Total & 4.406 & 113 & 14,1 \\
\hline Rata - Rata & 1.102 & 37,67 & 4,7 \\
\hline
\end{tabular}

Sumber : Hasil olahan data 2017

Berdasarkan hasil olahan data menunjukkan bahwa prosentase perkembangan jumlah penjualan tiket dalam 4 tahun ( tahun 2011 s/d tahun 2014 ) mengalami peningkatan volume penjualan tiket yang cukup tinggi pada tahun 2012 sebesar 96 lembar atau 9,4 $\%$. Terjadinya peningkatan penjualan tiket karena adanya pengaruh penetapan harga tidak terlalu tinggi perbedaannya. Tetapi pada tahun 2013 dan 2014 terjadi penurunan perkembangan volume penjualan dibandingkan tahun sebelumnya. Dengan penurunan perkembangan tingkat penjualan maka upaya yang dilakukan oleh perusahaan adalah dengan upaya memperbaiki strategi pemasaran untuk penjualan tiket.

Harga merupakan satu - satunya unsur bauran pemasaran yang memberikan pendapatan bagi perusahaan. Meskipun memutuskan harga akan sulit dilakukan menentukan harga sangat dipengaruhi oleh keuntungan yang diingankan tetapi harus memperhatikan harga pesaing, sehingga konsumen dapat menjangkau harga yang ditawarkan. Meskipun sebenranya harga mahal akan menjadi keuntungan yang sangat besar dan menjadikan laba jangka pendek pada perusahaan, tetapi bisa jadi menjadi senjata bagi perusahaan pesaing untuk mendapatkan konsumen yang lebih banyak dan juga harga tinggi tidak akan mampu dijangkau oleh konsumen. Untuk lebih jelasnya akan disajikan data perkembangan harga jual tiket pada PT Pakem Tours \& Travel, yaitu :

Tabel 3. Perkembangan harga jual tiket tahun $2011-2014$

\begin{tabular}{ccc}
\hline Tahun & Harga Jual Tiket / Lembar ( Rp ) & $\begin{array}{c}\text { Perkembangan Persentase } \\
\text { ( \% })\end{array}$ \\
\hline $\mathbf{2 0 1 1}$ & Rp. 764.000 & - \\
$\mathbf{2 0 1 2}$ & Rp. 809.000 & 5,9 \\
$\mathbf{2 0 1 3}$ & Rp. 846.000 & 4,58 \\
$\mathbf{2 0 1 4}$ & Rp. 869.000 & 2,72 \\
\hline & Rata - Rata Perkembangan ( \% ) & 4,4 \\
\hline
\end{tabular}

Sumber : PT Pakem Tours \& Travel Makassar

Berdasarkan tabel 3 di atas, dapat dijelaskan bahwa rata - rata harga jual tiket meningkat sebesar $4,4 \%$ pertahun.
Dimana dapat dilihat bahwa dalam tahun 2011 - 2012 meningkat sebesar 5,9\%, tahun 2012 - 2013 meningkat 4,58\%, 
dan tahun 2013 - 2014 meningkat

sebesar $2,72 \%$.

\section{Harga Biaya dan Promosi}

Dalam rangka memperlancar penjualan tiket maka upaya yang dilakukan oleh perusahaan adalah dengan melakukan penerapan promosi. Dimana dalam melakukan pemasaran tiket oleh perusahaan maka salah satu faktor yang berpengaruh adalah melalui penerapan strategi promosi.
Kegiatan promosi yang dilakukan oleh perusahaan adalah dengan melakukan kontak langsung / personal selling kepada konsumen dimaksudkan untuk dapat menjadikan konsumen untuk melakukan pembelian ulang.

Berikut ini adalah penyajian biaya promosi yang dikeluarkan oleh perusahaan PT Pakem Tours \& Travel dalam penjualan tiket yang dapat dilihat pada tabel 4 sebagai berikut:

Tabel 4. Biaya promosi dalam pemasaran tiket

\begin{tabular}{ccc}
\hline Tahun & $\begin{array}{c}\text { Biaya Promosi } \\
(\text { Rp ) }\end{array}$ & $\begin{array}{c}\text { Peningkatan / Penurunan } \\
\text { Biaya Promosi ( \% ) }\end{array}$ \\
\hline $\mathbf{2 0 1 1}$ & Rp. 8.760 .000 & - \\
$\mathbf{2 0 1 2}$ & Rp. 10.583 .000 & 20,81 \\
$\mathbf{2 0 1 3}$ & Rp. 11.750 .000 & 11,03 \\
$\mathbf{2 0 1 4}$ & Rp. 10.130 .000 & $-13,79$ \\
\hline Rata - Rata Perkembangan ( \%) & 6,02 \\
\hline
\end{tabular}

Sumber : PT Pakem Tours \& Travel Makassar

Berdasarkan tabel 4 di atas, dinyatakan bahwa rata -rata biaya promosi terjadi peningkatan sebesar $6,02 \%$ setiap tahunnya, dimana hal ini dapat dilihat dari tahun 2011/2012 meningkat sebesar 20,81 $\%$, tahun 2012 / 2013 meningkat sebesar $11,03 \%$, namun tahun 2013 / 2014 menurun sebesar $-13,79 \%$. Hal ini sejalan dengan Nawal (2008) bahwa dengan peningkatan promosi maka akan berpengaruh terhadapa peningkatan penjualan tiket.

Tabel 5. Hasil regresi dengan SPSS 20

\section{Analisis Regresi Linier Berganda}

Analisis regresi berganda adalah suatu analisis yang dipergunakan untuk menentukan sifat hubungan antara harga jual $\left(X_{1}\right)$, biaya promosi $\left(X_{2}\right)$ dengan volume penjualan (Y) dengan bentuk persamaan sebagai berikut :

$\mathrm{Y}=B_{O}+B_{1} X_{1}+B_{2} X_{2}+\mathrm{e}$

Analisis regresi linier berganda menggunakan program SPSS versi 20, yang dapat dilihat pada tabel berikut ini :

\begin{tabular}{|c|c|c|c|c|c|c|}
\hline & \multirow[t]{2}{*}{ Model } & \multicolumn{2}{|c|}{ Unstandardized Coefficiets } & \multirow{2}{*}{$\begin{array}{c}\begin{array}{c}\text { Standardized } \\
\text { Coefficients }\end{array} \\
\text { Beta } \\
\end{array}$} & \multirow[t]{2}{*}{$\mathbf{t}$} & \multirow[t]{2}{*}{ Sig } \\
\hline & & $\mathrm{B}$ & Std. Error & & & \\
\hline \multirow[t]{3}{*}{1.} & (Contant) & 308.426 & 288.904 & & 1.068 & .479 \\
\hline & Harga jual & .00 & .000 & 639 & 1.645 & .348 \\
\hline & Biaya Promisi & $1.755 \mathrm{E}-5$ & .000 & .405 & 1.044 & .486 \\
\hline \multirow[t]{2}{*}{2.} & (Constant) & 232.532 & 285.838 & & .814 & .501 \\
\hline & Harga Jual & .001 & .000 & .907 & .3 .044 & .093 \\
\hline
\end{tabular}

a.Dependent Variabel: Volume Penjual $\quad \mathrm{Y}=308.426+0,639 X_{1}+0,405 X_{2} .+$ e,

Berdasarkan tabel 5, hasil analisis regresi berganda tentang harga jual dan biaya promosi yang berpengaruh terhadap volume penjualan adalah hal ini menunjukkan bahwa jika harga jual dan biaya promosi tidak berubah maka nilai volume penjualan tiket sebesar 308.426 lembar, pengaruh atas volume 
penjualan tiket akan meningkat sebesar $0.639 \%$ dan $0.405 \%$.

Selain itu untuk mengetahui hubungan atau korelasi antara harga jual $\left(X_{1}\right)$ dan Tabel 6. Nilai korelasi biaya promosi $\left(X_{2}\right)$ dengan volume penjualan $(Y)$ yaitu sebagai berikut

\begin{tabular}{lllll}
\hline Model & R & R Square & Adjusted R Square & $\begin{array}{l}\text { Std. Error of the } \\
\text { Estimate }\end{array}$ \\
\hline $\mathbf{1}$ & $.957^{\mathrm{a}}$ & .915 & .745 & 27.006 \\
$\mathbf{2}$ & $.907^{\mathrm{b}}$ & .822 & .734 & 27.608 \\
\hline
\end{tabular}

a. Predictors: (Constant), Biaya Promosi, Harga Jual

b. Predictors: (Contant, Harga Jual

Tabel pada model (1) menjelaskan besarnya nilai korelasi antara harga $\left(X_{1}\right)$ dengan volume penjualan (Y) yaitu sebesar 0,957. Dari output tersebut diperoleh koefisien diterminasi (R2) pada model (1) sebesar 0,915, yang berarti bahwa pengaruh variabel bebas (harga) terhadap variabel terikat (volume penjualan) adalah sebesar 91,5\%.

Pada model (2) menjelaskan besarnya nilai korelasi antara harga $\left(X_{1}\right)$ dan biaya promosi $\left(X_{2}\right)$ terhadap volume penjualan
(Y) yaitu sebesar 0,907 dan menjelaskan besarnya prosentase pengaruh variabel harga dan biaya promosi terhadap volume penjualan yaitu sebesar 0,822 atau $82,2 \%$ sehingga dapat disimpulkan besarnya pengaruh harga $\left(X_{1}\right)$ terhadap volume penjualan (Y) sebesar 91,5\%, dan pengaruh biaya promosi $\left(X_{2}\right)$ terhadap volume penjualan $(\mathrm{Y})=9,3 \%(91,5 \%$ $82,2 \%)$.

\section{Uji F}

Tabel 7. Uji F

\begin{tabular}{|c|c|c|c|c|c|c|}
\hline & Model & Sum of Squares & df & Mean Square & $\mathbf{F}$ & Sig \\
\hline \multirow[t]{3}{*}{1.} & Regression & 7855.663 & 2 & 3927.832 & 5.385 & $.291^{\mathrm{a}}$ \\
\hline & Residual & 729.337 & 1 & 729.337 & & \\
\hline & Total & 8585.000 & 3 & & & \\
\hline \multirow[t]{3}{*}{2.} & Regression & 7060.627 & 1 & 7060.627 & 9.264 & $.093^{\mathrm{b}}$ \\
\hline & Residual & 1524.373 & 2 & 762 & & \\
\hline & Total & 8585.000 & 3 & & & \\
\hline
\end{tabular}

a. Predictors: (Contant), Biaya Promosi, Harga Jual

b. Predictors: (Contant), Harga Jual

c. Dependent Varianle: Volume Penjual

Uji $\mathrm{F}$ adalah untuk mengetahui apakah variabel - variabel independen secara simultan memiliki pengaruh yang signifikan terhadap variabel dependen. Derajat kepercayaan yang digunakan adalah 0,05. Apabila nilai $F$ hasil perhitungan lebih besar dari pada nilai $\mathrm{F}$ menurut tabel maka hipotesis alternatif, yang menyatakan bahwa semua variabel independen secara simultan berpengaruh signifikan terhadap variabel dependen.

Dari tabel diperoleh nilai Fhitung sebesar 5,385 dengan nilai probabilitas (sig) $=$ 0,291 . Nilai Fhitung $(5,385)>$ Ftabel $(2,692)$ maka Ho diterima. 


\section{KESIMPULAN DAN SARAN}

\section{KESIMPULAN}

Dari hasil pembahasan mengenai pengaruh harga dan biaya promosi maka dapat disajikan kesimpulan sebagai berikut:

1. Hasil analisis regresi maka diperoleh persamaan $\mathrm{Y}=308.426$ $+0,639 \mathrm{X}_{1}+0,405 \mathrm{X}_{2}$, di mana b0 $=308.426$ merupakan nilai konstant, dengan kata lain jika harga jual dan biaya promosi tidak berubah maka nilai penjualan tiket sebesar 308.426 lembar, $b_{1} X_{1}=$ 0,639 yang artinya pengaruhnya atas volume penjualan tiket meningkat sebesar $63,9 \%, \mathrm{~B}_{2} \mathrm{X}_{2}=$ 0,405 yang artinya pengaruhnya atas volume penjualan meningkat sebesar 40,5\%.

2. Dari hasil analisis korelasi antara harga dan biaya promosi, menunjukkan bahwa terdapat hubungan yang signifikan dalam peningkatan volume penjualan sebab $\mathrm{R}=0,957$, sedangkan $R^{2}=$ 0,915 yang artinya ada pengaruh dan hubungan yang simultan antara harga dan promosi terhadap peningkatan volume penjualan tiket.

\section{SARAN}

Hasil dari analisis penelitian, maka saran yang dapat diberikan yaitu :

1. Penting bagi perusahaan untuk memberikan perhatian lebih terhadap kebijakan marketing mix terutama menyangkut penentuan harga jual. Dimana akan berpengaruh langsung pada ttingkat volume penjualan serta loyalitas pelanggan

2. Perusahaan harusnya meningkatkan anggaran jumlah biaya promosi.Besarnya biaya promosi secara signifikan akan mempengaruhi peningkatan volume penjualan tiket, serta perusahaan harus menentukan penggunaan media yang paling tepat, yaitu menyesuaikan dengan pangsa pasar.

\section{UCAPAN TERIMAKASIH}

Puji syukur penulis panjatkan kehadirat Allah Subhanahu Wata'ala karena dengan rahmat dan hiyah-Nyalah sehingga penulis dapat menuntaskan artikel ini dengan judul "Pengaruh Harga Dan Biaya Promosi Terhadap Peningkatan penjualan Tiket pada PT. Pakem Tours dan Travel Makassar".

Artikel ini dapat terselesaikan berkat adanya dukungan dan kontribusi moril yang sangat berharga terutama dari pihak keluarga hingga saat ini

\section{DAFTAR PUSTAKA}

Hardjanto.2005.Biaya dan Pemasaran. Yogyakarta.Unit Penerbit dan Percetakan

Nawal.2008. Pengaruh Produk dan Promosi terhadap Keputusan Pembelian Rumah pada PT Karyaeda Alam. Tesis, Program Studi Manajemen

\section{Rangkuti,2009.Manajemen}

Bisnis.Yogyakarta : Graha Ilmu

Subagyo.2010.Manajemen.

Bisnis.

Yogyakarta: Graha Ilmu

Sugiyono.2004.Metode Penelitian Bisnis. Bandung: CV. Alvabeta

Sutojo,2009.Pengantar Bisnis. Jakarta : Graha Pena

Swastha. Basu.2001.Pengantar Bisnis. Yogyakarta : Ekonisia.

Tjiptono.2009.Biaya dan Pemasaran. Yogyakarta: Unit Penerbit dan Percetakan

UIT, A., \& Toalib, R. (2020). Analysis Of The Influence of Company Growth On Corporate Value In Gowa Motor Group Companies Listed In Bosowa Automotive. Economy Deposit 
Journal (E-DJ), 2(1), 75-82.

https://doi.org/10.36090/edj.v2i1.745 